\title{
Context Matters: Measuring Nationalism in the Countries of the Former Czechoslovakia
}

\author{
Miloslav Bahna* \\ Institute for Sociology, Slovak Academy of Sciences, Bratislava, Slovak Republic \\ ${ }^{*}$ Corresponding author. Email: miloslav.bahna@savba.sk
}

\begin{abstract}
This paper compares nationalism in the two ex-Czechoslovak countries-the Czech and Slovak republics. The aim is to analyze the measurement of nationalism in the 1995, 2003, and 2013 International Social Survey Program (ISSP) National Identity surveys. According to the nationalism measures from the ISSP survey - which are frequently used by authors analyzing nationalism-both countries experienced a significant rise in nationalism in the 1995 to 2013 period. Moreover, invariance testing of the nationalism latent variable confirms the possibility of comparing levels of nationalism between Czechia and Slovakia over time. However, the associations between nationalism, as measured in the study, and concepts related to nationalism-such as xenophobia, protectionism, or assertive foreign policy-suggest that what is measured as nationalism in 1995 is very different from what is measured in 2013. This is explained by a change of context which occurred in both countries between 1995 and 2013. While answering the same question had a strong nationalistic connotation in 1995, this was not the case in 2013. Based on our findings we advise against using the analyzed "nationalism" items as measurement of nationalism even beyond the two analyzed countries.
\end{abstract}

Keywords: nationalism; Czech Republic; Slovakia; measurement invariance; ISSP

\section{Introduction}

Comparative social science is often a challenging undertaking. This is generally the case when comparing such culturally and historically embedded concepts as nationalism or national pride. While there have been several attempts to rank various nations participating in international comparative surveys by national pride (Smith and Jarkko 1998, Smith and Kim 2006, Smith 2009), there also has been criticism mentioning the pitfalls of such comparisons (Dražanová 2015, Latcheva 2010).

From this point of view, the starting point of our study is modest. We compare nationalism in one of the world's culturally closest societies-the Czech and Slovak Republics, the states which came into existence after the so called "Velvet Divorce" of Czechoslovakia in 1993. Moreover, we do so under nearly ideal conditions building on three waves of the International Social Survey Program (ISSP) National Identity module fielded in 1995, 2003 and 2013 in both countries-almost perfectly mapping the period of Czech and Slovak independence which started in 1993.

This comparison could shed light on the inconsistencies between the previous empirical results and theoretically underpinned expectations. While there is a general expectation of excited nationalism in newly established countries (Weiss 2003, 395), both ex-Czechoslovak countries scored poorly in international comparisons of national pride-a concept closely related to nationalism - done with the 1995 and 2003 ISSP data. A high level of national pride was typically measured in new world countries like the USA or Venezuela with ex-socialist countries 
trailing last in international comparisons (Smith 2009). The position of Slovakia and the Czech Republic was not an exception to the rule. Both countries scored relatively low in international comparison. Moreover, the split-blamed by some on Slovak nationalism-left the Slovaks in their independent country less nationalistic than the Czechs. On the other hand, the 1995-2013 comparison shows a general rise of nationalism in both countries. Literature reviews on the subject, however, conclude that globalization and economic integration erode national identification (see Tilley and Heath 2007).

There is one further reason for studying nationalism in former Czechoslovakia. The split of it was - together with the dissolutions of the USSR and Yugoslavia-one of the reasons why the study of nationalism gained new momentum in the 1990s.

While-as indicated above-the Czech-Slovak comparison is interesting also theoretically, in our paper this comparison provides a background for a methodological case study: The principal focus of our article is on the instruments used to measure nationalism in previous research. The question we ask is if they are valid measures of nationalism across time and across societies. Our hypothesis is that in changing contexts these measures fail to measure the same concept.

First, the article gives background on nationalism measurement and a brief overview of Czechoslovak history from its establishment to its dissolution and the fates of the newly established republics after the split. The following section summarizes various approaches to the measurement of nationalism, patriotism, and national pride and the discussion of their dimensionality and mutual relationships. Next, descriptive statistics are presented and a multivariate model explaining nationalism is calculated for the two states at three points in time. This section is concluded by measurement invariance testing of the nationalism latent variable. In the next section, the associations between nationalism and related concepts are calculated. The conclusion discusses the context dependency of the tools used to measure nationalism in the ISSP National identity module.

\section{Background and Literature Review: A Short History of Czechoslovakia-an Evitable Couple, an Evitable Divorce}

As Karen Henderson writes, "The demise of the Czech and Slovak Federative Republic on 31 December 1992 was surrounded by a sense of evitability" (Henderson 1995, 111). Yet, it was not only the demise of Czechoslovakia which was surrounded by a sense of evitability. The creation of Czechoslovakia on the remains of the Austro-Hungarian monarchy on October 28, 1918, happened only three years after the Cleveland Agreement-the first of several public statements of support for a common state-had been signed by Czech and Slovak ethnic organizations in the USA.

The newly created country was a multi-national state where the number of Germans, living mostly in the Czech part of the new republic, surpassed the number of Slovaks. Furthermore, a large Hungarian minority was living in the Slovak part on the border with Hungary. To be able to make the case of creating a self-determining nation-state to the wining allies of World War I, a fictitious "Czechoslovak" nation was heralded by the 1920 Czechoslovak constitution. ${ }^{1}$ Since the early years of its existence, a strong movement calling for Slovak autonomy within Czechoslovakia had existed. When Slovak autonomy was granted in 1938, it was in the crippled version of Czechoslovakia stripped of its border lands to Germany and Hungary. The autonomy lasted for few months until Slovakia declared independence and became a vassal state of Germany. At the time, the Czech part became a protectorate of the Third Reich. The post-war brief reinstatement of democratic Czechoslovakia saw the expulsion of three million Czechoslovak Germans who were blamed for cooperating with the Nazis. That move left the territory of the nowadays Czech Republic almost purely ethnically Czech. In a similar, yet less radical move, a part of the Hungarian population of Slovakia had to resettle in Hungary in exchange for ethnic Slovaks who 
voluntarily agreed to resettle from Hungary to Slovakia. Also, due to the war related deportations of Jews, when the communists took power in early 1948, Czechoslovakia had much less ethnic diversity than its democratic pre-war predecessor.

The demise of Communist rule in November 1989 opened a new era in solving the "Slovak question." Calls for independence of Slovakia were formulated, but did not gain majority support in Slovakia. Hungarian minority parties sprang up (about 10\% of Slovak citizens are ethnic Hungarians) and the anti-Hungarian card started to be played by parts of the new Slovak political elite. Two years later, after tiring negotiations about competences of the federal level, the final decision to dissolve the federative state came in the fall of 1992.

Soon after the split reasons why the "Velvet Divorce" had taken place were sought. According to Paal Sigurd Hilde, many used the "term 'Slovak nationalism' in their explanation" $(1999,648)$. Hilde's opinion on that matter was that Czech, rather than Slovak, nationalism was to blame for the split (1999, 663). Ladislav Holy agrees that "The prevailing feeling in the Czech landsBohemia and Moravia-is that the disintegration of Czechoslovakia in 1993 was the result of Slovak nationalism, anti-Czech sentiment and Slovak separatism" (1996, 6). He adds that "Czech nationalism tends to be overshadowed by the manifest Slovak nationalism even for many Czechs, who, paradoxically, manifest it through its vehement denial,"2 (Holy 1996, 7). Hislope (1998) speaks in this regard of a rise of nationalism prior to the split which he explains by aspirations of both Slovak and Czech elite members.

Other authors interpret the split more as a result of different attitudes to post-communist transformation and the incompatibility of the political elites in both countries than of differences between Czechs and Slovaks themselves (see Henderson 1995, 1997). Indeed, based on 1994 data, Whitefield and Evans suggest a broad similarity between the two nations (Whitefield and Evans 1999).

The post-Czechoslovak republics took diverging paths after 1993. Slovakia, ruled by a nationalist and authoritarian-leaning Prime Minister Mečiar missed the invitation to the first round of the eastern enlargement of NATO which included the Czech Republic (as well as neighboring Poland and Hungary). Slovakia was called the (black) "hole in the map of Europe" by US Secretary of State Madeleine Albright in 1997 (see Krause 2003). After the demise of Vladimír Mečiar in 1998, Slovakia was able to catch up with the Czechs and joined the EU in 2004 in the first round of its eastern enlargement. After that, both ex-Czechoslovakia countries became part of the Schengen area in 2007. If European integration was a must for the Czech (re)public, in the eyes of a significant part of Slovaks it became a symbol in the battle for the geopolitical leaning of the new state. In 2009 Slovakia went one step further in the European integration when it adopted the Euro.

A last noteworthy difference in the post-split development is the fact that, contrary to Slovakia, the Czech Republic started to attract a comparatively small-yet noticeable-immigration, mainly from the Slovak republic itself and ex-USSR countries, most notably from Ukraine. Eurostat figures for 2014 state that $4.1 \%$ of the Czech population is formed by immigrants, compared to as little as $1.1 \%$ in Slovakia.

To sum up the points relevant to our argument, while there are almost no ethnic minorities in the Czech Republic, there is a certain number of immigrants. On the other hand, there are almost no immigrants in Slovakia, yet there is a sizable and politically important Hungarian minority.

Now, before we proceed to the measurement of nationalism in the two ex-Czechoslovak countries, we provide a brief overview of relationships between nationalism, patriotism, and national pride.

\section{Measuring Nationalism, Patriotism, and National Pride}

Influenced by Adorno et al. (1950), works dealing with the measurement of nationalism often discuss it together with chauvinism and patriotism as one of the three dimensions of national identity. Since it is outside the scope of our article to go fully into the vast discussion about the 
relationship between nationalism and related concepts, we only provide here an overview of the approaches taken while analyzing ISSP data.

Tom Smith (2009) acknowledges a close link between national pride, patriotism, and nationalism (198). Other authors explicitly see nationalism and patriotism as two separate forms of national attachment (Green et al. 2011). Hjerm (1998) refuses the link between national pride and nationalism claiming that national pride, contrary to nationalism is not an ideology but a sentiment. He proposes a different division-one between political and natio-cultural national pride. Dražanová (2015) inspired by Latcheva (2010) proposes a model for the Czech Republic where nationalism is one of four dimensions of national pride. Coenders and Scheeppers, referring to Adorno et al. (1950), avoid using the term national pride and define chauvinism and patriotism as two dimensions of nationalism (Coenders and Scheepers 2003). A note worth mentioning is that when defining nationalism, most of the cited authors do not refer to it as an ideology of putting the nation's interest first-that being the definition of the term found in encyclopedias. They rather distinguish between nationalism and patriotism merely with regard to the notion of national superiority present in nationalism (de Figueiredo and Elkins 2003).

Most works analyzing nationalism or national pride empirically are based on the National Identity module from the ISSP survey series, some use also World Values Survey (WVS) or Eurobarometer data (de Figueiredo and Elkins 2003, Tilley and Heath 2007). If WVS and Eurobarometer surveys are used, a simple "How proud are you to be [NATIONALITY]" question is used to measure national pride. Tilley and Heath (2007) note a broad similarity between the item and the questions measuring national pride in the ISSP. ${ }^{3}$

The ISSP questionnaire includes two sets of questions related to feelings of pride toward the nation, state, or some aspects of it. Smith (2009) calls the sets "general national pride" and the "domain specific national pride." While the former taps the general attachment to the nation, the latter contains questions evaluating several domains of the country's political and cultural setting. Various authors use different combinations of those questions to construct indexes of nationalism, patriotism, nationalism/chauvinism, or national sentiment. An overview of these operationalizations based on the "general national pride" set in the ISSP is provided in Table 1.

The question with regard to our study is which items should we pick to analyze nationalism in the ex-Czechoslovak countries. Based on the literature review summarized in Table 1 we construct our nationalism latent variable from the four items which - according to most authors are measures of nationalism or nationalist sentiment (BPlace, BCountry, SWrong, RCitizen). Each of the four items is measured on a five point Likert scale coded from -2 to 2 . The answers are combined to create an overall score of nationalism ranging from -10 to 10 . This score is also the dependent variable in the OLS regression presented in Table 3.An alternative would be to use only the two items (BPlace, BCountry) used by Davidov $(2011,2009)$. The disadvantage of this choice would be the impossibility of evaluating measurement invariance with only two items. Obviously, in Table 1 there is no clear agreement whether the respective items measure patriotism, nationalism, chauvinism or nationalistic sentiment. However, it is clear that most authors link the chosen items with nationalism. The four items are also generally internally consistent with a Cronbach's alpha between 0.627 and 0.743 and they form one factor in 2003 and 2013 ISSP data in both countries. ${ }^{4}$

Before we proceed to the results of our analysis, one note is necessary. To account for the fact that there is a varying degree of ethnic homogeneity in the Czech and Slovak republics, in both countries we include in our analysis only persons who declare themselves as belonging to the majority. As members of national minorities generally have lower levels of national pride (see Dražanová 2015, Smith 2009) this increases slightly the average level of nationalism in both countries, more notably in Slovakia. 
Table 1. Different operationalizations of nationalism using ISSP National Identity survey items.

\begin{tabular}{|c|c|c|c|c|c|c|c|c|c|c|c|}
\hline & $\begin{array}{l}\text { (Coenders } \\
\text { and } \\
\text { Scheepers } \\
\text { 2003) }\end{array}$ & $\begin{array}{l}\quad \text { (de } \\
\text { Figueiredo } \\
\text { and Elkins } \\
\text { 2003) }\end{array}$ & $\begin{array}{l}\text { (Sinnott 2005; } \\
\text { O'Rouke and } \\
\text { Sinnott 2002) }\end{array}$ & $\begin{array}{l}\text { (Heath } \\
\text { and } \\
\text { Tilley } \\
\text { 2005) }\end{array}$ & $\begin{array}{l}\text { (Huddy } \\
\text { and } \\
\text { Khatib } \\
\text { 2007) }\end{array}$ & $\begin{array}{l}\text { (Ceobanu } \\
\text { and } \\
\text { Escandell } \\
\text { 2008) }\end{array}$ & $\begin{array}{l}\text { (Vlachová } \\
\text { and } \\
\text { Řeháková } \\
\text { 2009) }\end{array}$ & $\begin{array}{l}\text { (Davidov } \\
\text { 2009; } \\
\text { Davidov } \\
\text { 2011) }\end{array}$ & $\begin{array}{l}\text { (Hjerm } \\
\text { and } \\
\text { Schnabel } \\
\text { 2010) }\end{array}$ & $\begin{array}{l}\text { (Green } \\
\text { et al. } \\
2011)\end{array}$ & $\begin{array}{l}\text { (Latcheva } \\
\text { 2010) } \\
\text { (Dražanová } \\
\text { 2015) }\end{array}$ \\
\hline $\begin{array}{l}\text { The world would be a better place if people } \\
\text { from other countries were more like the } \\
\text { [COUNTRY'S NATIONALITY]. (BPlace) }\end{array}$ & $\mathrm{N} / \mathrm{CH}$ & $\mathrm{N}$ & $P$ & $P$ & $\mathrm{~N}$ & $\mathrm{CH}$ & $\mathrm{N}$ & $\mathrm{N}$ & $N(S)$ & $\mathrm{N}$ & $\mathrm{N} / \mathrm{CH}$ \\
\hline $\begin{array}{l}\text { Generally speaking, [COUNTRY] is a better } \\
\text { country than most other countries. } \\
\text { (BCountry) }\end{array}$ & - & $\mathrm{N}$ & $P$ & $P$ & $\mathrm{~N}$ & $\mathrm{CH}$ & $\mathrm{N}$ & $\mathrm{N}$ & $N(S)$ & $\mathrm{N}$ & $\mathrm{N} / \mathrm{CH}$ \\
\hline $\begin{array}{l}\text { People should support their country even if } \\
\text { the country is in the wrong (SWrong) }\end{array}$ & $\mathrm{N} / \mathrm{CH}$ & $\mathrm{N}$ & $\mathrm{CH}$ & $\mathrm{P}$ & - & $\mathrm{CH}$ & $\mathrm{N}$ & - & $N(S)$ & $\mathrm{N}$ & - \\
\hline $\begin{array}{l}\text { I would rather be a citizen of [COUNTRY] } \\
\text { than of any other country in the world. } \\
\text { (RCitizen) }\end{array}$ & $\mathrm{N} / \mathrm{CH}$ & $\mathrm{N}$ & $P$ & $\mathrm{P}$ & - & $\mathrm{CH}$ & $P$ & - & $N(S)$ & $\mathrm{N}$ & - \\
\hline $\begin{array}{l}\text { When my country does well in international } \\
\text { sports, it makes me proud to be } \\
\text { [COUNTRY NATIONALITY]. }\end{array}$ & - & $\mathrm{N}$ & & $\mathrm{P}$ & - & - & $P$ & - & - & - & - \\
\hline $\begin{array}{l}\text { There are some things about [COUNTRY] } \\
\text { today that make me ashamed of } \\
\text { [COUNTRY]. }\end{array}$ & - & $P$ & & $\mathrm{P}$ & - & - & $P$ & - & $N(S)$ & - & - \\
\hline
\end{tabular}

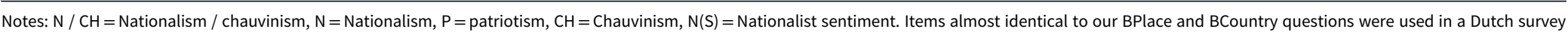
to operationalize chauvinism (Lubbers and Meuleman 2016). 


\section{Analysis}

\section{Descriptive Statistics and Multivariate Explanations of Nationalism}

Table 2 provides a basic overview of our measure of nationalism and of related items in the ISSP National Identity surveys of 1995,2003 , and $2013 .^{5}$ Average value, standard deviation, and information about statistical significance of the difference between the Czech and Slovak Republics are calculated. Table 2 also includes information about the relative position of the Czech Republic and Slovakia among the countries which participated in the respective ISSP rounds ranking the countries from those scoring highest to those scoring lowest on each item.

We see that until 2013, the level of nationalism was higher in the Czech Republic. In both countries there has been a significant increase in nationalism between 1995 and 2013 in international comparisons. This means that by 2013 , the average level of nationalism rose in both countries from being comparatively low to a level above the ISSP average. ${ }^{6}$

As already noted, the indicator which is close to our nationalism measure is the simple question of how proud people are to be nationals of their country. Here we have only two time points as the question was not part of the 1995 questionnaire. In both years Slovaks in Slovakia were more proud than Czechs in the Czech Republic were. With regard to the CloseCountry question, there is no consistent pattern. In 1995 the feeling of closeness was similar in both countries; in 2003 it was stronger in Slovakia while it was the other way around in 2013.

Interesting are the two dimensions of xenophobia. ${ }^{7}$ While immigrants were perceived more often as a threat in 1995 Slovakia, the situation reversed in 2003. A significant observation being that, in both countries, the index has notably fewer missing answers in 2013 than previously. The most probable explanation of this high share of missing answers was the almost complete lack of experience with immigrants and a missing discourse on the topic in 1990s ex-Czechoslovakia. In international comparison, we see a relative strengthening of anti-immigrant sentiments in both countries, making the Czech Republic in 2003 and 2013 the second most xenophobic of the ISSP countries with Slovakia trailing only a little behind in the overall ranking. The comparison of the perception of immigration as an opportunity is similar to the previous variable and also ends in 2013 with the Czech Republic being the second least optimistic about the opportunities immigrants bring.

The support for international solutions of environmental problems (variable ISolutions) has always been higher in the Czech Republic with both countries scoring below the average in the international comparison.

A noticeable change has occurred in answers to the question if the country should follow its own interest even if it could result in a conflict. In both countries, there has been a significant increase in agreement to this assertion. The agreement was more pronounced in the Czech Republic at all three occasions.

With regard to protectionism, there has been above average support for protectionism in both countries compared with other countries. With initially more support for protectionism in the Czech Republic, there was no significant difference between the two countries in 2013.

The last two questions-ShareCustoms and PreserveMinorities-show a more generous attitude of Slovaks toward minorities in the country. This comes as rather surprising given the track record of playing the "Hungarian card" in Slovak politics and the absence of a sizable ethnic minority in the Czech Republic. It is, however, in line with the observed stronger anti-immigrant sentiment of the Czech public. Nevertheless, the context in which this question is asked differs in both countries. While being asked about ethnic minorities ${ }^{8}$ Slovaks most likely imagine members of the Hungarian minority. In case of the Czech Republic, the respondents might be referring to the much more negatively perceived Roma or to immigrants.

A multivariate model explaining nationalism is presented in Table 3. Higher values of the dependent variable refer to more nationalism. The analysis was conducted with $\mathrm{R}$ software. Missing answers were deleted listwise. The model includes basic demographic variables like age, 



\begin{tabular}{|c|c|c|c|c|c|c|c|c|c|c|c|c|}
\hline & \multicolumn{4}{|c|}{1995} & \multicolumn{4}{|c|}{2003} & \multicolumn{4}{|c|}{2013} \\
\hline & avrg. & missing & diff. sig. & position & avrg. & missing & diff. sig. & position & avrg. & missing & diff. sig. & position \\
\hline \multicolumn{13}{|l|}{$\begin{array}{l}\text { Isolutions } \\
\text { ("For cert }\end{array}$} \\
\hline Czech Republic & $0.949(1.064)$ & $5.9 \%$ & \multirow[b]{2}{*}{+} & $14 / 24$ & $0.766(0.980)$ & \multirow{2}{*}{\multicolumn{2}{|c|}{$\begin{array}{l}9.9 \% \\
0.0 \%\end{array}$}} & $22 / 35$ & $0.699(0.999)$ & $3.8 \%$ & \multirow[t]{2}{*}{ * } & $27 / 37$ \\
\hline Slovakia & $0.690(1.119)$ & $9.1 \%$ & & $20 / 24$ & $0.806(0.900)$ & & & $21 / 35$ & $0.617(0.979)$ & $6.1 \%$ & & $22 / 37$ \\
\hline \multicolumn{13}{|l|}{$\begin{array}{l}\text { IInterests } \\
\text { ("[COUN] }\end{array}$} \\
\hline Czech Republic & $-0.117(1.318)$ & $6.3 \%$ & \multirow{2}{*}{$* \star * *$} & $17 / 24$ & $0.360(1.130)$ & $7.3 \%$ & & $19 / 36$ & $0.472(1.101)$ & $2.8 \%$ & \multirow{2}{*}{ *** } & $17 / 37$ \\
\hline Slovakia & $-0.515(1.264)$ & $5.8 \%$ & & $23 / 24$ & $0.289(1.070)$ & $0.0 \%$ & & $22 / 36$ & $0.312(1.074)$ & $6.6 \%$ & & $22 / 37$ \\
\hline \multicolumn{13}{|l|}{$\begin{array}{l}\text { Protectionism } \\
\text { (“[COUNTRY] } \\
\text { television sho }\end{array}$} \\
\hline Czech Republic & $0.595(0.978)$ & $6.9 \%$ & $* \star *$ & $6 / 24$ & $0.537(0.877)$ & $13.1 \%$ & \multirow{2}{*}{ NA } & $12 / 36$ & $0.559(0.920)$ & $4.5 \%$ & \multirow{2}{*}{ ** } & $12 / 37$ \\
\hline Slovakia & $0.387(0.955)$ & $10.1 \%$ & NA & $11 / 24$ & $0.649(0.789)$ & $0.1 \%$ & & $10 / 36$ & $0.617(0.845)$ & $6.9 \%$ & & $10 / 37$ \\
\hline \multicolumn{13}{|l|}{$\begin{array}{l}\text { ShareCustoms } \\
\text { ("It is impossi }\end{array}$} \\
\hline Czech Republic & $0.451(1.269)$ & $4.7 \%$ & \multirow[b]{2}{*}{ 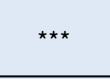 } & $11 / 24$ & 0.483 (1.129) & $7.2 \%$ & \multirow[b]{2}{*}{ 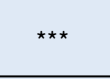 } & $13 / 35$ & $0.630(1.150)$ & $1.7 \%$ & \multirow[b]{2}{*}{ 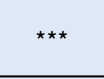 } & $10 / 37$ \\
\hline Slovakia & $-0.004(1.340)$ & $2.5 \%$ & & $21 / 24$ & $0.150(1.120)$ & $3.8 \%$ & & $27 / 35$ & $0.096(1.159)$ & $1.7 \%$ & & $29 / 37$ \\
\hline \multicolumn{13}{|c|}{$\begin{array}{l}\text { PreserveMinorities } \\
\text { ("Ethnic minoritie }\end{array}$} \\
\hline Czech Republic & $0.145(1.227)$ & $7.2 \%$ & \multirow{2}{*}{$* \star *$} & $13 / 24$ & $0.038(1.125)$ & $9.5 \%$ & \multirow[b]{2}{*}{+} & $21 / 35$ & $-0.229(1.113)$ & $2.8 \%$ & \multirow[b]{2}{*}{+} & $27 / 37$ \\
\hline Slovakia & $0.352(1.162)$ & $5.3 \%$ & & $11 / 24$ & $0.184(0.983)$ & $5.0 \%$ & & $18 / 35$ & $0.245(0.983)$ & $3.1 \%$ & & $17 / 37$ \\
\hline
\end{tabular}

Notes: Multiple-group confirmatory factor analysis is used to test for significance in comparisons of latent means (see Holmes Finch and French 2015). Standard deviation in parentheses.

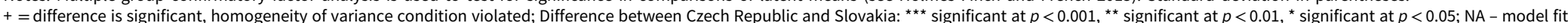

is unacceptable; - model did not converge. 
Table 3. Explaining nationalism, OLS regression, standardized coefficients.

\begin{tabular}{|c|c|c|c|c|c|c|c|c|c|c|c|c|}
\hline & \multicolumn{6}{|c|}{ Czech Republic } & \multicolumn{6}{|c|}{ Slovakia } \\
\hline & 1995 & & 2003 & & 2013 & & 1995 & & 2003 & & 2013 & \\
\hline Male (dummy) & -0.104 & $\star \star$ & -0.005 & & -0.022 & & 0.006 & & -0.005 & & -0.021 & \\
\hline Age (years) & 0.112 & ** & 0.165 & 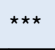 & 0.145 & 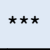 & 0.132 & $\star \star \star \star ~$ & 0.082 & * & 0.120 & $\star \star$ \\
\hline Education (years) & -0.190 & $\star \star \star$ & -0.131 & $\star \star$ & -0.133 & 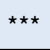 & -0.141 & 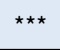 & -0.256 & $\star \star \star$ & -0.103 & $\star \star$ \\
\hline Did not vote in last elections & -0.015 & & 0.004 & & -0.027 & & 0.010 & & -0.005 & & -0.051 & \\
\hline Voted for current ruling party & -0.088 & * & -0.006 & & 0.046 & & 0.281 & 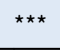 & -0.090 & * & 0.077 & * \\
\hline Subjective social class / Top-bottom & -0.021 & & -0.014 & & 0.034 & & -0.056 & & 0.065 & & 0.098 & * \\
\hline $\mathrm{R}^{2}$ & 0.089 & & 0.054 & & 0.048 & & 0.149 & & 0.095 & & 0.048 & \\
\hline $\mathrm{N}$ & 642 & & 609 & & 1456 & & 979 & & 746 & & 794 & \\
\hline
\end{tabular}

*** significant at $p<0.001,{ }^{\star *}$ significant at $p<0.01,{ }^{*}$ significant at $p<0.05$ Source: ISSP 1995, 2003, 2013.

education, and gender which have previously been reported as being associated with nationalism. We included also a measure of subjective social class and variables on political support for the current ruling party and participation in previous elections. The last two variables are included to test the assumption that support for government is connected with a higher score on our measure of nationalism and to verify if nonvoters are more authoritarian leaning and nationalistic as suggested by Schatz, Staub, and Lavine (1999).

As can be observed in Table 3, there is a general positive association between age and nationalism. This, together with a negative association between education and nationalism, comes as no surprise and has been observed in previous research (Green et al. 2011). With the exception of 1995 Czech data, there is no significant difference between nationalism among men and women. This runs against expectations, as previous research suggests that men display higher levels of nationalism (Green et al. 2011). We see that in both countries our models explain less variance with each consecutive ISSP round.

With regard to our main argument, noteworthy are the 1995 and 2013 results for Slovakia. As can be seen, the respondents who voted for the ruling parties in the 1995 module displayed far more nationalism. In 1995 the variable "voted for the current ruling party" is indeed the strongest predictor of all models in Table 3. This is easily explained by the intense political struggle which was taking place in post-1993 Slovakia between the ruling authoritarian-leaning Prime Minister Mečiar in coalition with a party of Slovak nationalists (both defining themselves as fathers of independent Slovakia) and their opponents who disagreed with the geopolitical heading of Slovakia under their rule and were less charmed by Slovak independence. The observation that voters of the ruling parties were displaying higher levels of nationalism than their opponents is also well in line with the evaluation of local experts (Gyárfášová et al. 2001).

Another important result is the positive association between subjective social class and nationalism in the 2013 Slovakia sample. This runs against the observations of Tilley and Heath (2007) who report more pride in Britishness among the lower classes. ${ }^{9}$ Similarly, Haller et al. $(2009,224)$ summarize the view of several authors that national affiliation and feelings are reactions to the process of modernization arising among those who are not able to come to grips with those processes-that is, the losers of modernization.

In our view, this is an important and unexpected result which indicates that the social base of nationalism in Slovakia has changed between 1995 and 2013. In 2013, people who evaluate their 
subjective position in society more positively tend to also be more nationalistic. Observing those changes in the associations between explanatory variables and nationalism, we might ask if the concept we try to measure has remained the same throughout the observed period. In the next section, we employ invariance testing to provide a statistically rigorous answer to this question.

\section{Measurement Invariance of Nationalism Between 1995 and 2013}

As - in our operationalization - nationalism is a latent variable measured by four items, we are able to do measurement invariance testing using multiple-group confirmatory factor analysis. The aim is to establish if those four items measure the same latent variable in both countries at all three points in time. Without going into further detail, we use the concept of testing measurement invariance which was introduced by Byrne et al. (1989). To test for measurement invariance of our nationalism latent variable, the "measurementInvariance" function included in the lavaan package for $\mathrm{R}$ was used (for an introduction to the lavaan package see Rosseel 2012).

Table 4 summarizes the measurement invariance tests of the nationalism variable which we used in the previous parts of the paper. Typically, three levels of measurement invariance are recognized: 1. configural invariance - testing if the factor structure of national pride is the same in both samples; 2, metric invariance - testing if the slopes of national pride are comparable; 3 ) from the perspective of our study, scalar invariance is the most important as only when scalar invariance is achieved, mean levels of national pride can be compared across samples. If full scalar invariance cannot be achieved, partial scalar invariance is considered to be sufficient (see Byrne et al. 1989, Steenkamp and Baumgartner 1998).

As we can see, for the Czecho-Slovak comparison, full scalar invariance of our measure of nationalism can only be achieved in 1995. However, partial scalar invariance can be achieved for almost all combinations of 1995, 2003, and 2013 data from both countries. An exception is the 1995 and 2013 comparison in Slovakia, where the criterion for confirming partial scalar invariance is missed by a small margin.

Table 4 also includes measurement invariance tests for protectionism and xenophobia latent variables. In the case of xenophobia, with one exception, metric invariance could be achieved in all combinations. This means that associations between xenophobia and nationalism can be explored. However, (partial) scalar invariance could not be established in most cases and comparisons of levels of xenophobia, such as in Table 2 are questionable.

With regard to the protectionism latent variable, metric invariance cannot be established in four cases. This indicates that the comparison of means (Table 2) as well as the drop in association of protectionism and nationalism between 1995 and 2003 (Table 5) need to be interpreted with caution.

If we summarize the invariance testing results of our nationalism latent variable, we may conclude that it measures the same concept in 1995, 2003, and 2013 in both countries. Moreover, (partial) scalar invariance can be established for most Czech-Slovak comparisons and comparing levels of nationalism is also possible. The finding that there has been gradual increase in nationalism in both countries therefore seems to stand on solid ground. Our study results seem to be compatible with the findings of Davidov (2009), who established (partial) scalar invariance for a two-item nationalism index based on ISSP data (see Table 1).

However, is the concept measured by our nationalism index really nationalism? If so, it should associate with related concepts as expected by its definition. To establish if this is the case, we will now map the associations between our measure of nationalism and the concepts listed in Table 2.

\section{Nationalism and Related Concepts: On the Changing Meaning of Liking a Country}

The relationships between nationalism as it is measured by our indicators and preferences conceptually related with nationalism are summarized in Table 5. Instead of reporting simple 

Table 5. Association between the latent variable nationalism and related concepts.

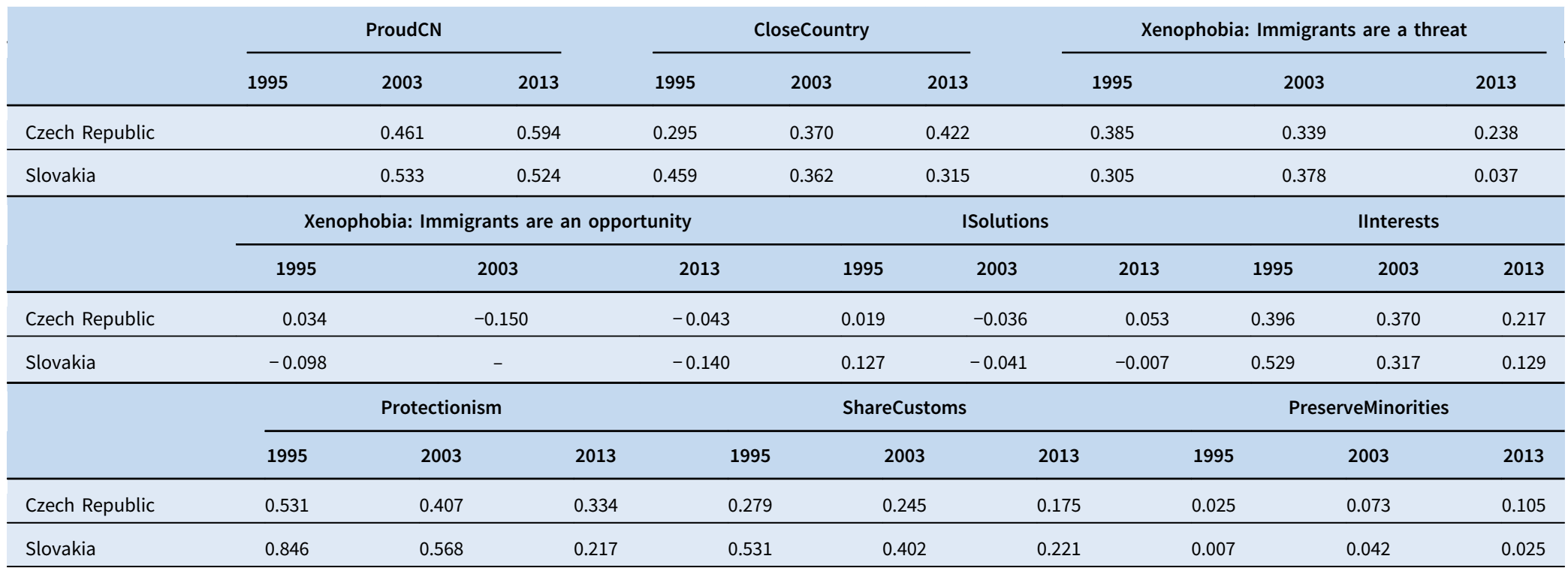

- $=$ the model did not converge.

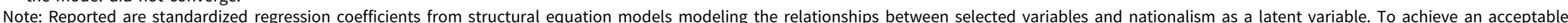
model fit, in some cases covariance between exogenous variables has been added.

Source: ISSP 1995, 2003, 2013. 
correlations, the reported associations are standardized coefficients from structural equation models which include the relationships between the analyzed concept and nationalism as our latent variable. This approach accounts for measurement error and allows for a robust interpretation of the studied associations.

Typically, the most studied association is the one between nationalism and xenophobia. De Figueiredo and Elkins (2003) who distinguish two dimensions of national pride-namely, nationalism and patriotism-show in their paper on USA data that while nationalism is well connected with out-group hostility (that is, xenophobia), patriotism is not. Looking at Table 1, we see that our nationalism measurement is identical to the one used by De Figueiredo and Elkins. The connection between nationalism and perception of immigrants as a threat in the two ex-Czechoslovakia countries is shown in Table 5. While the connection is clearly present in 1995 and 2003, it experiences a steep drop in the 2013 data, especially in Slovakia. Indeed, in the 2013 Slovak sample there was almost no connection between nationalism and fear of immigrants. We consider this an important sign that the very essence of what we measure as "nationalism" in 1995 and in 2013 is different, especially in Slovakia.

If we investigate the connection between nationalism and protectionism, which is analyzed by O'Rouke and Sinnott (2002) and which Ceobanu and Escandell (2008) define as one of the four dimensions of "national feelings" we find a similar pattern. Through 1995 - 2003 - 2013, the connection between nationalism and protectionism ${ }^{10}$ is declining, again, more steeply in Slovakia. While the standardized regression coefficient was 0.846 in the 1995 Slovak sample, it declined to 0.217 in 2013.

With regard to other variables potentially related to nationalism, like IInterests or ShareCustoms, we also see a moderate association in 1995 gradually declining through 2003 to 2013 in both ex-Czechoslovak countries. As in the previous cases, the decline is steeper in Slovakia. This is another indication that the latent variable we measure in 2013 is different than in 1995. The Interest variable is used for example by Kunovich (2009) who finds that people with a civic understanding of national identity tend to agree less with an assertive following of national interests in international politics.

The connection between nationalism, ProudCN and CloseCountry remains in place through 1995 to 2013. This suggests that our operationalization of nationalism retained a medium-strong link with the single ProudCN question. However, the connection is weaker than observed by Tilley and Heath (2007) in the British case. We see fewer clear patterns for ISolutions and PreserveMinorities which do not associate with nationalism at any of the three time points neither in the Czech Republic nor in Slovakia.

If we now review the evidence gathered so far, we have to ask: Do the four proposed indices indeed measure nationalism - the foreigners-unfriendly face of national identity? In 2013 Slovak data, there is practically no connection between xenophobia and nationalism. Moreover, the association between nationalism and assertive foreign politics (IInterests) is minimal, the connection with protectionism is a quarter of what it used to be in 1995 and the connection between nationalism and the expectation of sharing Slovak customs to become "fully Slovak" is down to 0.221 from 0.531 in 1995 .

Next, rather than heralding the emergence of a non-aggressive and non-xenophobic kind of nationalism, we will explain why we blame the changing context in which the nationalism questions were asked in the ex-Czechoslovak countries for this apparent change.

\section{Discussion and Conclusion}

\section{From Measuring Nationalism to a Measurement of Patriotism?}

The invariance testing results seem to suggest that the four questions used to measure nationalism in the three ISSP rounds fielded over a time span of 18 years measure the same latent 
concept throughout the observed period. In 1995 this latent variable was close to nationalismdemonstrated by a strong connection to protectionism, assertive foreign politics, high expectations of sharing customs within a nation, and a clear connection to xenophobia. However, a gradual change has occurred in the three successive rounds of the ISSP National Identity survey and by 2013, the connection of our latent variable to nationalism is almost nonexistent in Slovakia and a weak one in the Czech Republic.

We explain this shift by a relatively dramatic change of the context in which the questions used to construct the variable were asked. As noted, in 1995 both countries were newly established independent states in the middle of a transition from state socialism. Both processes were more problematic in Slovakia. Firstly, the transition to a market economy was connected with a steeper decline in living standards and a higher unemployment rise than in the Czech Republic. Secondly, in the 1990s Slovak society was going through an internal struggle about its future geopolitical leaning and the character of its democracy. Still, only a few years after the split of Czechoslovakia, a lot of people found it difficult to identify themselves with the new state. This group largely overlapped with those who opposed the ruling style and geopolitical leaning of the Slovak Prime Minister Mečiar (Szomolányi 1994).

If questions like "Generally speaking, the [Czech / Slovak] Republic is a better country than most other countries" or "I would rather be a citizen of the [Czech / Slovak] Republic than of any other country in the world" were asked in 1995, there is a high probability they would tap nationalists who do not mind the trials and tribulations of the post-communist transformation because they value the newly gained independence. The very same question is, as it seems, understood differently in 2013. Using the criteria of gross domestic product or the Human Development Index, both ex-Czechoslovak republics are indeed better than most other countries. In 2013, the first question is positively associated with subjective social class in both countries. Indeed, it is plausible to believe that those who employ a positive attitude toward their personal social standing tend to see the international position of their country also more positively. We should bear in mind this shift of context when we attempt to explain the apparent rise in nationalism observed in Table 2. Contrary to Dražanová (2015) and Latcheva (2010), we do not see Slovak or Czech nationalism as particular or different. We rather say that the tools that are used are particularly unfit for the purpose if they are used in different contexts. This is what happened in the studied period in case of the two countries of the former Czechoslovakia.

So, even beyond the Czechoslovak context, we believe there is a problem of contextuality embedded in the questions used to measure nationalism in our paper. Answering the question if your country is better than most others with a "yes" does not have the same meaning in Somalia and in Switzerland. While in the first case it is probably a measure of nationalism or patriotism, in the latter case, for many respondents this may be understood as a factual statement without any nationalistic or patriotic connotations. We assert that a person "agreeing" with the claim that Switzerland is the best country might be more nationalistic or patriotic than another person in Switzerland who disagrees. However, agreeing that Switzerland is the best and agreeing that Somalia is the best hardly refers to the same level of nationalism. And yet, this is what we assume in international comparisons.

Also questions like, "The world would be a better place if people from other countries were more like the [Czechs / Slovaks]" could have different connotations in countries with a higher level of immigration. Here it could be understood as referring to people from other countries already living in the country where the survey is fielded. On the other hand, this remains a bizarre theoretical question in a country with (almost) no immigrants like Slovakia.

Another complication is that the substance of the more general concept of national pride is determined by the entity the pride is directed to. That is, a nationally proud person in a nationalistic authoritarian government (as was the Slovak government back in 1995) is more 
likely to be also xenophobic and protectionist. This is, however, not the case for a person declaring pride in an open and democratic nation state. We assert that, at least in Slovakia in 2013, the respondents claimed affinity to a different country than they did in 1995 . While this is to some extent true also for the Czech Republic, in the Slovak case this change has been quite dramatic and helps explain the different dynamics and more stable associations of the measured latent variable (we assumed was a measure of nationalism) to nationalism-related concepts in the Czech Republic.

Indeed, can we say that our nationalism variable has transformed from being a measure of nationalism toward a measure of patriotism? This seems to come close to what we see was happening. Nevertheless, this is quite an unexpected result given the consensus of many authors referenced in Table 1 who see the items we used as measures of nationalism, even chauvinism.

\section{Who is More Proud and Who is More Nationalistic?}

It turns out that comparing nationalism-even between such culturally close countries as the two ex-Czechoslovak republics-is more challenging than initially thought.

If nationalism cannot be measured and compared within ex-Czechoslovakia throughout the 1995 to 2013 period, what does the comparison of the related concepts summarized in Table 2 tell us about nationalism in the Czech Republic and Slovakia? At first glance, it seems, that the main difference between Czechs and Slovaks is in their attitude toward people who "do not share customs and traditions" and ethnic minorities. Here the Czech public is consistently less welcoming and supportive. However, considering the fact that Slovakia has a sizable Hungarian minority, while in the Czech Republic the typical "other" would be an immigrant or a Roma this difference could be an artifact of the different contexts. Yet, looking at the xenophobia index, this difference probably cannot be fully explained by the context. While there are comparatively very few sympathies for immigrants in both countries, it is the Czech public that ranks as the second most xenophobic among ISSP participants since $2003 .^{11}$

Another noteworthy difference seemed to be the answers to the ProudCN question. While Slovak pride in being Slovak is below average, Czechs tend to be even more reluctant to declare pride in being Czechs. Of the 37 countries/samples ${ }^{12}$ in which the question was asked in 2013, only two had a less proud population.

To conclude, we have to note that comparing nationalism between countries is a complex problem. We believe that even time series comparisons of the same country are problematic when using questions from the ISSP general pride battery. The shift of Slovakia from being 21 out of 24 to being 14 out of 37 countries does not mean there was more nationalism in 2013 Slovakia than back in 1995. Moreover, it does not necessarily mean, there is more patriotism either. It may simply be a sign that 2013 Slovakia was, according to many indicators, a better country to live in and claim affinity to than the 1995 version of it.

There has been criticism of the validity of the questions used by the ISSP aimed at particular aspects of national pride which were often used as measures of patriotism (see Latcheva 2011, Blank et al. 2001). Also, recently a measure to assess cosmopolitanism was questioned by Braun et al. (2017). However, so far there has been no such criticism toward the measures analyzed in our paper which have been most often used to operationalize nationalism. Moreover, the invariance testing done by Davidov $(2011,2009)$ suggests the items were successful at measuring nationalism. As we demonstrated, this does not seem to be the case. Unfortunately, it appears that if we define nationalism as an "outlook which gives an absolute priority to the values of the nation over all other values and interests" (Hroch 1993, 6), we can say very little about the prevalence of these kinds of feelings in a country with the ISSP data.

Financial support. This work was supported by the Slovak Research and Development Agency under Grant APVV-14-0527 and Grant APVV-0309-11. 


\section{Notes}

1 We can draw a parallel here with the arguments used in establishing Yugoslavia in the same time when a united Yugoslav nation encompassing Serbs, Croats, and Slovenes was proclaimed (Muršič 2000).

2 In an October 1990 survey, Czech respondents were quite critical about the "typical Slovak nature:" While nationalism and chauvinism were the second most often mentioned negative features of Slovaks, they did not appear among the negative features of Czechs as reported by Slovak respondents (Frič, Bútorová, and Rosová 1992).

3 "Moreover, though this question may be simple, it actually correlates very well with more sophisticated measures of patriotism and pride. The 2003 ISSP includes a battery of questions that attempt to tap feelings of national pride; these are similar to the questions that make up the scale of pride used by McCrone and Surridge (1998)" (Tilley and Heath 2007, 665).

4 In 1995 a second factor consisting of RCitizen is identified in Slovakia while SWrong is a second factor in the Czech data.

5 The following three data files are used: ISSP Research Group (1998): International Social Survey Program: National Identity I - ISSP 1995. GESIS Data Archive, Cologne. ZA2880 Data file Version 1.0.0; ISSP Research Group (2012): International Social Survey Program: National Identity II - ISSP 2003. GESIS Data Archive, Cologne. ZA3910 Data file Version 2.1.0;; ISSP Research Group (2015): International Social Survey Program: National Identity III - ISSP 2013. GESIS Data Archive, Cologne. ZA5950 Data file Version 2.0.0. Please note, that while the Czech ISSP National Identity surveys were fielded in 1995, 2003, and 2013, in Slovakia all the module rounds were fielded a year later.

6 As noted with the Czech and Slovak data, international comparison in Table 2 is also only using the answers of majority respondents from the countries included.

7 To measure xenophobia we use the same four statements about immigrants as Hjerm (2003, 1998). However, based on factor analysis results, which suggest a two factor solution, we distinguish between perception of immigrants as a threat and seeing them as an opportunity.

8 In both countries the questionnaire uses the term "national minorities."

9 Coenders and Scheepers (2003) use objective social class (EGP) as an indicator of social position in their explanation of chauvinism and ethnic exclusionism. They find that lower classes tend to display higher levels of both.

10 To measure protectionism we use three ISSP variables as proposed by Ceobanu and Escandell (2008).

11 However, such a comparison is problematic given the fact that we were unable to establish (partial) scalar invariance for the two xenophobia dimensions.

12 The former Eastern and Western part of Germany are included as two separate samples. Three Belgian regions were also sampled separately.

\section{References}

Adorno, Theodor W., Else Frenkel-Brunswik, Daniel J. Levinson, and R. Nevitt Sanford. 1950. The Authoritarian Personality. New York: Harper \& Row.

Blank, Thomas, Peter Schmidt, and Westle Bettina. 2001. "Patriotism'-a Contradiction, a Possibility or an Empirical Reality?” ECPR Workshop 26: National Identity in Europe 1:1-26. Grenoble.

Braun, Michael, Dorothée Behr, and Juan Díez Medrano. 2017. "What Do Respondents Mean When They Report to Be 'Citizens of the World'? Using Probing Questions to Elucidate International Differences in Cosmopolitanism.” Quality \& Quantity.

Byrne, Barbara M., J. Shavelson Richard, and Bengt Muthén. 1989. “Testing for the Equivalence of Factor Covariance and Mean Structures: The Issue of Partial Measurement Invariance.” Psychological Bulletin 105 (3): 456-466.

Ceobanu, Alin M., and Xavier Escandell. 2008. "East Is West? National Feelings and Anti-Immigrant Sentiment in Europe.” Social Science Research 37 (4): 1147-1170.

Chen, Fang Fang. 2007. "Sensitivity of Goodness of Fit Indexes to Lack of Measurement Invariance." Structural Equation Modeling: A Multidisciplinary Journal 14 (3): 464-504. 
Coenders, Marcel, and Peer Scheepers. 2003. "The Effect of Education on Nationalism and Ethnic Exclusionism: An International Comparison.” Political Psychology 24 (2): 313-343.

Davidov, Eldad. 2009. "Measurement Equivalence of Nationalism and Constructive Patriotism in the ISSP: 34 Countries in a Comparative Perspective.” Political Analysis 17 (1): 64-82.

Davidov, Eldad. 2011. "Nationalism and Constructive Patriotism: A Longitudinal Test of Comparability in 22 Countries with the ISSP.” International Journal of Public Opinion Research 23 (1): 88-103.

de Figueiredo, Rui J. P. Jr., and Elkins Zachary. 2003. "Are Patriots Bigots? An Inquiry into the Vices of In-Group Pride." American Journal of Political Science 47 (1): 171-188.

Dražanová, Lenka. 2015. "National Identity and the Interplay between National Pride and Ethnic Exclusionism: The Exceptional Case of the Czech Republic." Ethnopolitics 14 (3): 235-255.

Frič, Pavol, Zora Bútorová, and Tatiana Rosová. 1992. “Česko-Slovenské Vztahy v Zrkadle Empirického Výskumu.” Sociológia 24 (1-2): 43-74.

Green, Eva G. T., Oriane Sarrasin, Nicole Fasel, and Christian Staerklé. 2011. "Nationalism and Patriotism as Predictors of Immigration Attitudes in Switzerland: A Municipality-Level Analysis.” Swiss Political Science Review 17 (4): 369-393.

Gyárfášová, Olgga, Vladimír Krivý, and Marián Velšic. 2001. Krajina v Pohybe: Správa O Politických Názoroch a Hodnotách Ludí Na Slovensku. Bratislava: Inštitút pre verejné otázky.

Haller, Max, Gerd Kaup, and Regina Resler. 2009. "National Identity in Comparative Perspective." In The International Social Survey Program, 1984-2009: Charting the Globe, edited by Max Haller, Roger Jowell, and Tom W. Smith, $222-241$. London: Routledge.

Heath, Anthony F., and James R. Tilley. 2005. "British National Identity and Attitudes towards Immigration." International Journal on Multicultural Societies (IJMS) 7 (2): 119-132.

Henderson, Karen. 1995. "Czechoslovakia: The Failure of Consensus Politics and the Break-up of the Federation." Regional \& Federal Studies 5 (2): 111-133.

Henderson, Karen. 1997. "Transformation in the Czech and Slovak Republics: Elite Receptions and Responses." Harmonie Papers Special Issue: Governance Structures in Central and Eastern Europe 4 (vi): 89-102.

Hislope, Robert. 1998. "Can Evolutionary Theory Explain Nationalist Violence? Czechoslovak and Bosnian Illustrations." Nations and Nationalism 4 (4): 463-482.

Hjerm, Mikael. 1998. "National Identities, National Pride and Xenophobia: A Comparison of Four Western Countries." Acta Sociologica 41 (4): 335-347.

Hjerm, Mikael. 2003. "National Sentiments in Eastern and Western Europe." Nationalities Papers 31 (4): 413-429.

Hjerm, Mikael, and Annette Schnabel. 2010. "Mobilizing Nationalist Sentiments: Which Factors Affect Nationalist Sentiments in Europe?" Social Science Research 39 (4): 527-539.

Holmes, Finch William, and Brian F. French. 2015. Latent Variable Modeling with R. London: Routledge.

Holy, Ladislav. 1996. The Little Czech and the Great Czech Nation: National Identity and the Post-Communist Social Transformation. Cambridge, UK: Cambridge University Press.

Hroch, Miroslav. 1993. "From National Movement to the Fully-Formed Nation." New Left Review 198: 3-20.

Huddy, Leonie, and Nadia Khatib. 2007. "American Patriotism, National Identity, and Political Involvement." American Journal of Political Science 51 (1): 63-77.

Krause, Kevin Deegan. 2003. "Slovakia's Second Transition.” Journal of Democracy 14 (2): 65-79.

Kunovich, Robert M. 2009. “The Sources and Consequences of National Identification.” American Sociological Review 74 (4): 573-593.

Latcheva, Rossalina. 2010. "Nationalism versus Patriotism, or the Floating Border? National Identification and Ethnic Exclusion in Post-Communist Bulgaria." Journal of Comparative Research in Anthropology and Sociology 1 (2): 187-215.

Latcheva, Rossalina. 2011. "Cognitive Interviewing and Factor-Analytic Techniques: A Mixed Method Approach to Validity of Survey Items Measuring National Identity.” Quality and Quantity 45 (6): 1175-1199.

Lubbers, Marcel, and Roza Meuleman. 2016. "Participation in National Celebrations and Commemorations: The Role of Socialization and Nationalism in the Dutch Context." Social Science Research 55: 111-121.

Muršič, Rajko. 2000. "The Yugoslav Dark Side of Humanity: A View from a Slovene Blind Spot.” In Neighbors at War: Anthropological Perspectives on Yugoslav Ethnicity, Culture, and History, edited by Joel M. Harpern and David A. Kideckel, 56-77. University Park: Pennsylvania State University Press.

O'Rouke, Kevin H, and Richard Sinnott. 2002. "The Determinants of Individual Trade Policy Preferences: International Survey Evidence." In Brookings Trade Forum 2001, edited by Susan M. Collins and Dani Rodrik, 157-206. Washington, DC: Brookings Institution Press.

Rosseel, Yves. 2012. "Lavaan: An R Package for Structural Equation Modeling.” Journal of Statistical Software 48 (2): 1-36. http://www.jstatsoft.org/v48/i02/paper.

Schatz, Robert T., Ervin Staub, and Howard Lavine. 1999. "On the Varieties of National Attachment: Blind Versus Constructive Patriotism.” Political Psychology 20 (1): 151-174.

Sigurd Hilde, Paal. 1999. "Slovak Nationalism and the Break-up of Czechoslovakia." Europe-Asia Studies 51 (4): 647-665. 
Sinnott, Richard. 2005. "An Evaluation of the Measurement of National, Subnational and Supranational Identity in Crossnational Surveys.” International Journal of Public Opinion Research 18 (2): 211-223.

Smith, Tom W. 2009. "National Pride in Comparative Perspective." In The International Social Survey Programme, 19842009: Charting the Globe, edited by Max Haller, Roger Jowell, and Tom W. Smith, 197-221. London: Routledge.

Smith, Tom W., and Seokho Kim. 2006. "National Pride in Comparative Perspective." International Journal of Public Opinion Research 18 (1): 127-136.

Smith, Tom W, and Lars Jarkko. 1998. "National Pride: A Cross-National Analysis." GSS Cross - National Report No. 19, no. 19.

Steenkamp, Jan E. M. Benedict, and Hans Baumgartner. 1998. “Assessing Measurement Invariance in Cross National Consumer Research.” Journal of Consumer Research 25 (1): 78-107.

Szomolányi, Soňa. 1994. "Was The Dissolution Of Czechoslovakia Inevitable?" Scottish Affairs 8: 31-43.

Tilley, James, and Anthony Heath. 2007. “The Decline of British National Pride.” British Journal of Sociology 58 (4): $661-678$.

Vlachová, Klára, and Blanka Řeháková. 2009. "Identity of Non-Self-Evident Nation: Czech National Identity after the Breakup of Czechoslovakia and before Accession to the European Union.” Nations and Nationalism 15 (2): 254-279.

Weiss, Hilde. 2003. "A Cross-National Comparison of Nationalism in Austria, the Czech and Slovac Republics, Hungary, and Poland." Political Psychology 24 (2): 377-401.

Whitefield, Stephen, and Evans Geoffrey. 1999. "Political Culture Versus Rational Choice: Explaining Responses to Transition in the Czech Republic and Slovakia.” British Journal of Political Science 29 (1): 129-154.

Cite this article: Bahna, M. 2019. Context Matters: Measuring Nationalism in the Countries of the Former Czechoslovakia. Nationalities Papers 47: 2-19, doi:10.1017/nps.2018.21 